\title{
HOW TO COMMUNICATE LIVESTOCK HAZARD? AN APPROACH TO IMPROVE FARMERS' RISK PREPAREDNESS
}

\author{
Roni Jayawinangun*)1, Dikky Indrawan**), and Deddy Cahyadi Sutarman***) \\ ${ }^{*}$ Communication Science Program, Faculty of Social Sciences and Humanities, Pakuan University \\ Jl. Pakuan No. 1 RT.02/RW.06, Tegallega, Bogor Tengah Bogor 16143, Indonesia \\ **) School of Business, IPB University \\ Jl. Raya Padjadjaran, Bogor 16151, Indonesia \\ ${ }^{* * *}$ Centre for Tropical Animal Studies (Centras), IPB University \\ Jl. Raya Padjadjaran Bogor IPB Campus Baranangsiang, Bogor 16151, Indonesia
}

\begin{abstract}
Poultry industry is faced with a relatively high risk especially for small scale poultry farmers. Therefore, preparedness is needed to deal with risks. Communication in poultry is $\mathrm{s}$ essential. Its shown by one of the strategies of national preparedness for facing influenza pandemic, namely communication, information, and education (risk communication). Communication can improve the level of knowledge of farmers. The perceived needs of farmers that emerged include knowledge for a broader implementation of essential biosecurity. This paper aims to find out the standard form of small scale farmers communication with stakeholder and the impact of communication to improve farmers' risk preparedness. The selection of respondents used convineince sampling techniques to 33 farmers. Data analysis used descriptive analysis to found preparedness and communication that is done to reduce hazards. This study found that access communication farmers are Technical Support and Nucleus with two communication approaches, such as technical guidance and personal explanation. The contents of the communication consist of poultry health management, productivity, medicine, biosecurity, cleanliness the cage, and good farming practice. In general, small-scale farmers' preparedness activities in the Bogor district are limited to cleaning the cage regularly and cleaning cage after harvesting. Farmer with more communication activities has a positive impact on preparedness to face risks, especially related to restricting cage access, awareness of cage hygiene, and vaccination.
\end{abstract}

Keywords: preparedness, hazard, livestock, communication

\begin{abstract}
Abstrak: Industri perunggasan dihadapkan pada risiko yang relatif tinggi terutama bagi peternak unggas skala kecil. Oleh karena itu, kesiapan diperlukan untuk menghadapi risiko. Komunikasi dalam unggas sangat penting. Hal ini ditunjukkan oleh salah satu strategi kesiapsiagaan nasional dalam menghadapi pandemi influenza, yaitu komunikasi, informasi, dan pendidikan (komunikasi risiko). Komunikasi dapat meningkatkan tingkat pengetahuan petani. Kebutuhan yang dirasakan oleh para petani yang muncul termasuk pengetahuan untuk implementasi yang lebih luas dari biosecurity esensial. Makalah ini bertujuan untuk mengetahui bentuk standar komunikasi petani skala kecil dengan para pemangku kepentingan dan dampak komunikasi untuk meningkatkan kesiapan risiko petani. Pemilihan responden menggunakan teknik convineince sampling kepada 33 peternak. Analisis data menggunakan deskriptif untuk melihat kesiapan dan komunikasi yang dilakukan untuk mengurangi resiko. Penelitian ini menemukan bahwa petani akses komunikasi adalah dukungan teknis dan perusahaan inti dengan dua pendekatan komunikasi, seperti bimbingan teknis dan penjelasan pribadi. Materi komunikasi terdiri dari manajemen kesehatan unggas, produktivitas, obat-obatan, biosecurity, kebersihan kandang, dan praktik pertanian yang baik. Secara umum, kegiatan kesiapsiagaan petani skala kecil di Kabupaten Bogor sebatas pada membersihkan kandang secara teratur dan membersihkan kandang setelah panen. Petani dengan lebih banyak kegiatan komunikasi memiliki dampak positif pada kesiapan menghadapi risiko, terutama terkait dengan membatasi akses kandang, kesadaran akan kebersihan kandang, dan vaksinasi.
\end{abstract}

Kata kunci: kesiapsiagaan, bahaya, ternak, komunikasi

\footnotetext{
${ }^{1}$ Corresponding author:

Email: winangun.roni@gmail.com
} 


\section{INTRODUCTION}

The Indonesian poultry industry is a key sector for the national economy, supplying $65 \%$ of all animal protein and employing $10 \%$ of the national labor force. All over the country, though local production successfully copes with domestic demand, the potential for growth is high, consistent with expectations of rising GDP per capita (Ferlito and Respatiadi, 2018). Therefore, collaboration from various parties is needed. A collaboration between the government, integrated companies, and farmers may help to increase the feasibility of either vaccination or biosecurity-based mitigation strategy (Pramuwidyatama et al. 2019).

The poultry industry is faced with a relatively high risk of production because it is susceptible to disease and extreme weather changes. The risk can cause high mortality and cause loss (Vinanda et al. 2016). Problems with livestock also occur in distribution, which can spread disease if shelter hygiene is not considered (Kusumastuti et al. 2018). However, the small scale poultry farmers faced various institutional, political, technical, and financial constraints in developing large scale poultry farms, as well as to upgrade and standardize its biosecurity (Martindah et al. 2014). Small scale poultry farmers are sector 3 and sector 4 . Efforts to apply biosecurity measures in both the smallscale commercial (termed "sector 3" by the Food and Agriculture Organization (FAO) of the United Nations) and backyard (sector 4) poultry farms were largely unsuccessful. Structure of poultry chains, coordination, and protection of HPAI related to the application of biosecurity. There is no "one size fits all" strategy for HPAI control measures, therefore, government intervention is needed increasing incentives for better coordination of different value chains and improving institutional infrastructure is an important condition for HPAI control to be effective (Idris et al. 2010; Indrawan et al. 2018).

Communication in poultry is $\mathrm{s}$ essential. Its shown by one of the strategies of national preparedness for facing influenza pandemic, namely Communication, Information, and Education (risk communication) (BAPPENAS, 2015). Prevention and mitigation refer to the avoidance or limitation of the adverse impacts of hazards and related disasters, and preparedness refers to the knowledge and capacities necessary to effectively anticipate, respond to, and recover from these shocks (FAO, 2019). Communication methods can improve the level of knowledge of farmers. The perceived needs of farmers that emerged include knowledge, access to veterinary services, resources, and community involvement for a broader implementation of essential biosecurity. There is potential for improved production by educating farmers about infectious diseases and disease prevention measures. Such training should be participatory, involve communities and encourage participants to overcome practical and cultural obstacles (Wolff et al. 2019).

This paper aims to fill this gap by providing input specifically in the field of communication-related to hazard control in the poultry, such as HPAI. The objectives of this study are to (i) find out the standard form of small scale farmers communication with stakeholder and (ii) the impact of communication to improve farmers' risk preparedness.

\section{METHODS}

Survey to assess the communication implementation by small scale farmers in Bogor district. The location of the study was chosen purposively with some consideration (purposive). Bogor district was chosen as a research location. There are some considerations in selecting Bogor District. Bogor has a large number of farms with larger than average flock size compared to the other districts the FAO studied in Western Java, and 35\% of these farms have less than 5,000 birds. Most (90\%) small-scale broiler farms in Bogor have experienced HPAI H5N1 in their flock since it was first reported in Indonesia. In an outbreak situation, $20 \%$ of farms are likely to be infected in Bogor (Idris et al. 2010).

We developed a questionnaire aimed at ex-post evaluation of the identified HPAI control measures during 2013-2017, and ex-ante evaluation of future priorities concerning direct, indirect, and supportive measures. The questionnaire along with the framework can be used as an additional tool to improve current monitoring and evaluation practice in animal disease management.

Interviews of 33 farmers selected using the Convenience sampling and answers were verified by direct observation wherever possible during the farm visit. The study was designed using a descriptive quantitative approach to reveal a standard form of small scale farmers' communication with stakeholder and communication 
contents carried out by small scale farmers. The communication indicator in this study is to access farmers to source information. Source information in this study is veterinary services, resources, community involvement, and government (Pramuwidyatama et al. 2019; Wolff et al. 2019). Preparedness in this study regarding farmers experience related to hazard such as restrict cage access, cage cleanliness, personal cleanliness, vaccination, report quickly and clean the cage after harvest (FAO, 2005; Kasnodihardjo \& Friskarini, 2013; Kusumastuti et al. 2018).

\section{RESULTS}

\section{Common Form of Small Scale Farmers' Communication with Stakeholder}

Small scale farmers in Bogor district who accessed to source information in the amount of $54.5 \%$. This shows that there are still many farmers who only rely on experience in raising their livestock without any information from other parties. The communication involved two parties, namely Technical Support (TS) and Nucleus, through two communication approaches such as technical guidance and personal explanation. The form of communication by TS is carried out with a personal explanation, while the Nucleus is carried out with technical guidance (Table 1).

The contents of the communication consist of poultry health management, productivity, medicine, biosecurity, cleanliness the cage, and good farming practice. Poultry health management content is the most widely obtained by farmers, followed by medicine, productivity, cleanliness the cage, and biosecurity while the least is regarding good farming practice (Figüre 1).

According to Figure 2, the contents of communication are based on information sources, and it is known that farmers are more active in communicating with Technical Support compared to the nucleus. The content is shown by the answers of farmers who get poultry health management, productivity, medicine, biosecurity, cleanliness the cage, and good farming practice material content from TS while the nucleus only provides content related to poultry health management, productivity, biosecurity, and good farming practice.

Table 1. Small scale farmers communication

\begin{tabular}{cccc}
\hline Communication Activity & Percentage (\%) & Source & Approach \\
\hline Yes & 54,5 & Technical Support (TS) & Personal Explanation \\
\cline { 2 - 4 } No & & Nucleus & Technical Guidance \\
\hline
\end{tabular}

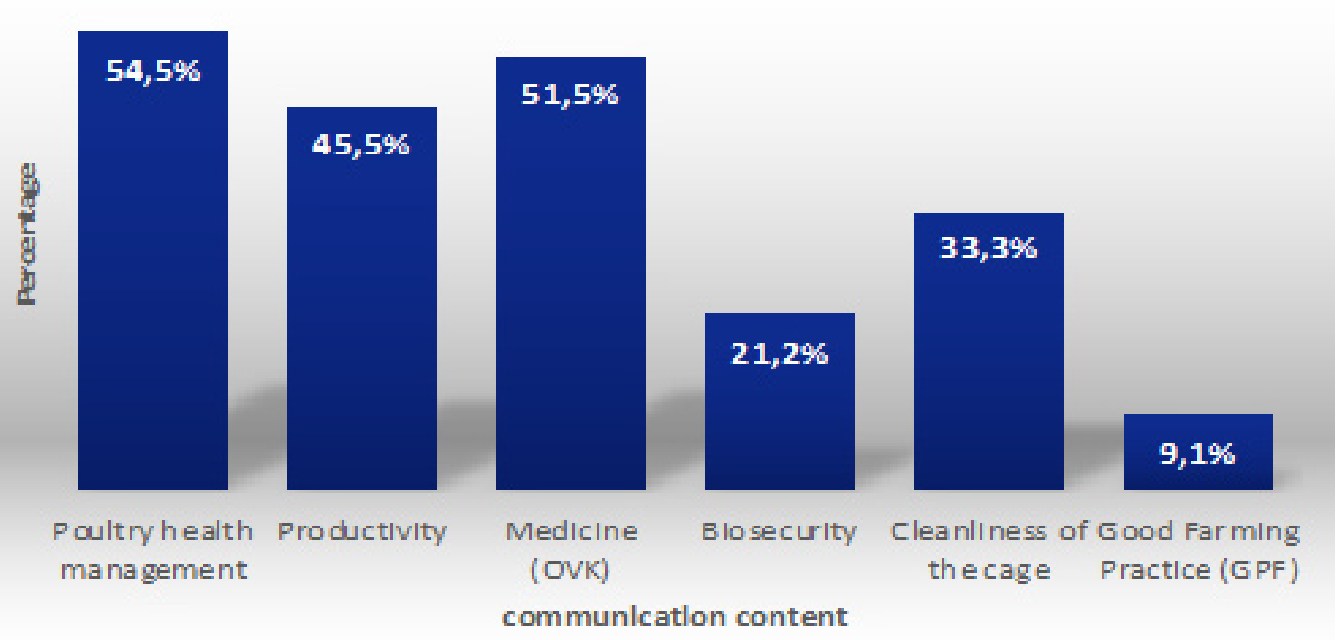

Figure 1. Distribution of farmer's based on communication content 


\section{Communication Impact to Improve Farmers' Risk Preparedness}

In general, small-scale farmers' preparedness activities in the Bogor district are cleaning the cage regularly, cleaning cage after harvesting, and reporting. Farmer with more communication activities has a positive impact on preparedness to face risks, especially related to restricting cage access, awareness of cage hygiene, and vaccination (Figure 3). The finding shows that the higher the farmer's communication activity, the more knowledge and the higher the level of hazard.

We have found that small scale farmers in Bogor District only communicate with Technical Support and nucleus, and no one communicates with government or associations. Based on this condition, we estimate that there are still some problems. First, the lack of active government and associations in establishing communication with farmers. Second, the lack of active farmers in communication activities with other parties outside the TS and nucleus.

In this study, we found that the more frequent communication activity the risk preparedness had. The active role of government and associations in communicating is needed by farmers in the form of socialization, technical guidance, training and even assistance to improve farmers' preparedness.

\section{Managerial Implication}

Managerial policies need to be developed which are expected to provide support for practice. The implication of the results of this study is the need for government to support in continuous communication between farmers and related parties (NGOs and universities), not only through socialization but also in the form of training, books or direct demonstrations to farmers.



Figure 2. Content communication based on information sources

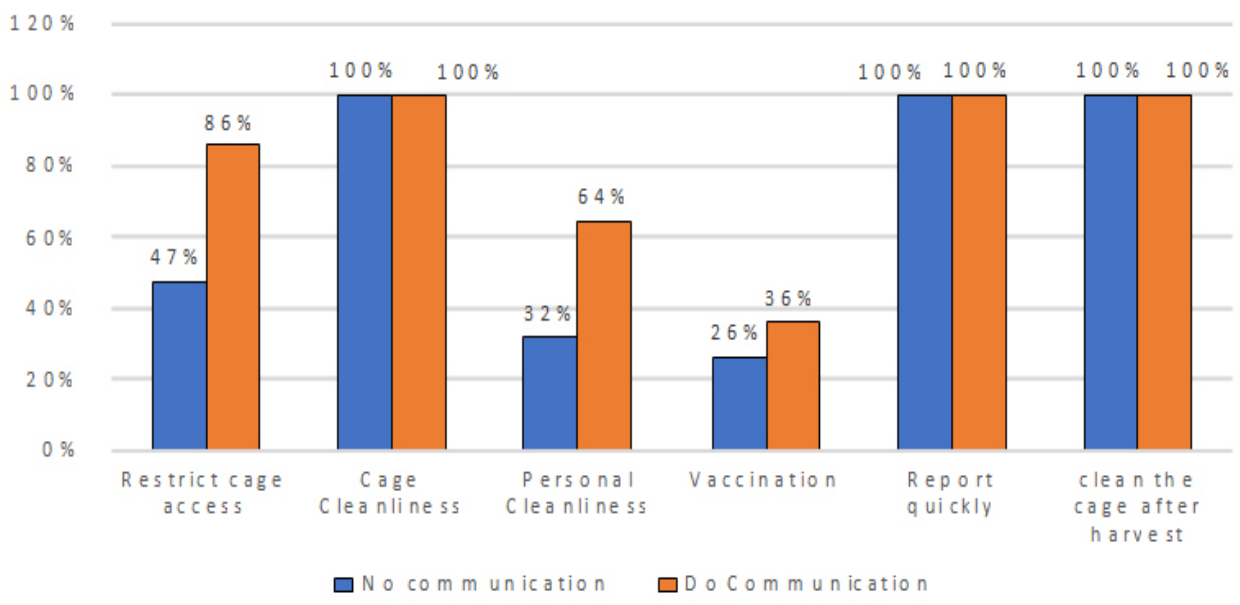

Figure 3. Association of farmers risk preparedness and communication activities 


\section{CONCLUSIONS AND RECOMMENDATIONS}

\section{Conclusions}

This study aims to improve small scale farmers (sector 3 and 4) risk preparedness through communication. This study reinforces the premise that communication is an important element in increasing farmers' knowledge in dealing with risks. The finding indicates access communication farmers are Technical Support (TS) and Nucleus with two communication approaches, such as technical guidance and personal explanation. The contents of the communication consist of poultry health management, productivity, medicine, biosecurity, cleanliness the cage, and good farming practice. In general, small-scale farmers' preparedness activities in the Bogor district are cleaning the cage regularly, cleaning cage after harvesting, and reporting. Farmer with more communication activities has a positive impact on preparedness to face risks, especially related to restricting cage access, awareness of cage hygiene, and vaccination.

\section{Recommendations}

Communication is an important element in increasing farmers' knowledge in dealing with risks. Continuous communication is needed between farmers and related parties (government, NGOs and universities), not only through socialization but also in the form of training, books or direct demonstrations to farmers.

\section{REFERENCES}

[BAPPENAS] Badan Perencanaan Pembangunan Nasional. 2015. Rencana strategis nasional pengendalian flu burung (Avian influenza) dan kesiapsiagaan menghadapi pandemi influenza 2006 - 2008.Jakarta: BAPPENAS.

[FAO] Food and Agriculture Organization. 2019. Prepare and respond: FAO in emergencies. http://www.fao.org/emergencies/how-we-work/ prepare-and-respond/en/ [5 Oct 2019].

[FAO] Food and Agriculture Organization. 2005. Pencegahan dan pengendalian flu burung (Avian influenza) pada peternakan unggas skala kecil.
Kamboja: FAO.

Ferlito C, Respatiadi H. 2018. Policy Reforms on Poultry Industry in Indonesia. CIPS (Center for Indonesian Policy Studies) 2019: 1-40. https:// doi.org/10.35497/271878.

Idris S, Palupi MF, Sudiana E, Unger F, Costard S, Pfeiffer DU. 2010. Qualitative risk assessment of HPAI H5N1 transmission between smallscale commercial broiler chicken farms in Bogor, Indonesia (Working Paper). IFPRI, ILRI and RVC.

Indrawan D, Rich KM, Van Horne P, Daryanto A, Hogeveen H. 2018. Linking supply chain governance and biosecurity in the context of HPAI control in Western Java: a value chain perspective. Frontiers in Veterinary Science 5:112. https://doi.org/10.3389/fvets.2018.00094.

Kasnodihardjo K, Friskarini K. 2013. Sanitasi Lingkungan Kandang, Perilaku, dan Flu Burung. Kesmas: National Public Health Journal 8(3):139-144. https://doi.org/10.21109/kesmas. v8i3.357.

Kusumastuti A, Cahyadi ER, Sarma M, Syamsidar S. 2018. Asessing biosecurity management practice along layer chicken chain in Bogor and Sukabumi. Jurnal Manajemen \& Agribisnis 15(3): 239-248. https://doi.org/10.17358/jma.15.3.239.

Martindah E, Ilham N, Basuno E. 2014. Biosecurity Level of Poultry Production Cluster (PPC) in West Java, Indonesia. International Journal of Poultry Science 13(7): 408-415. https://doi. org/10.3923/ijps.2014.408.415.

Pramuwidyatama MG, Hogeveen H, Saatkamp HW. 2019. A systematic evaluation of measures against highly pathogenic avian influenza (HPAI) in Indonesia. Frontiers in Veterinary Science 6(33):1-12. https://doi.org/10.3389/ fvets.2019.00033.

Vinanda G, Harianto, Anggraeni A. 2016. Resiko produksi ayam broiler dan preferensi peternak. Jurnal Manajemen dan Agribisnis 13(9): 50-58. https://doi.org/10.17358/JMA.13.1.50.

Wolff C, Abigaba S, Sternberg LS. 2019. Ugandan cattle farmers' perceived needs of disease prevention and strategies to improve biosecurity. BMC Veterinary Research 15(208). https://doi. org/10.1186/s12917-019-1961-2. 